Jurnal Cendekia Akuntansi

Kediri, Juni 2021

\title{
ANALISIS KINERJA KEUANGAN DINAS PERINDUSTRIAN DAN PERDAGANGAN KABUPATEN BLITAR
}

\author{
Rumanintya Lisaria Putri \\ Universitas Islam Balitar \\ E-mail: rumanintyalisariaputri@gmail.com
}

\begin{abstract}
Abstrak
Penelitian ini bertujuan untuk mengetahui Kinerja Keuangan Dinas Perindustrian dan Perdagangan Kabupaten Blitar Tahun 2016-2019 dilihat dari Rasio Kemandirian, Rasio Efektivitas dan Rasio Efisiensi. Penelitian ini merupakan penelitian deskriptif kuantitatif. Penelitian ini dilaksanakan di Dinas Perindustrian dan Perdagangan Kabupaten Blitar. Pengumpulan data menggunakan metode dokumentasi. Teknis analisis data yang digunakan deskriptif kuantitatif dengan perhitungan rumus Rasio Kemandirian, Rasio Efektivitas dan Rasio Efisiensi. Hasil analisis menunjukan bahwa Kinerja Keuangan Dinas Perindustrian dan Perdagangan Kabupaten Blitar Tahun 20162019 dilihat dari Rasio Kemandirian dapat dikategorikan Mandiri, karena rata-rata rasio Kemandiriannya sebesar 96,66\%. Rasio Efektivitas tergolong kurang efektif karena belum memenuhi target tiap tahunnya. Sedangkan Rasio Efisiensi tidak bisa dihitung dengan rumus rasio efisien karena biaya yang dikeluarkan untuk Pendapatan Asli Daerah pada Dinas Perindustrian dan Perdagangan Kabupaten Blitar biaya yang dikeluarkan bukan dari hasil Pendapatan Asli Daerah melainkan dari APBD. Maka dari itu Rasio Efisien di Dinas Perindustrian dan Perdagangan Kabupaten Blitar tidak bisa didefinisikan kinerja keuangannya.

Kata Kunci: Kinerja Keuangan, Rasio Kemandirian, Rasio Efektivitas, Rasio Efisiensi
\end{abstract}

\begin{abstract}
This study aims to see the financial performance of the Blitar Regency Industry and Trade Service 2016-2019 seen from the Independence Ratio, Effectiveness Ratio and Efficiency Ratio. This research is a quantitative quantitative research. This research was conducted at the Industry and Trade Office of Blitar Regency. Data collection using the documentation method. The technical analysis of the data used is descriptive quantitative with the calculation of the formula of the independence ratio, effectiveness ratio and efficiency ratio. The results of the analysis show that the Financial Performance of the Blitar Regency Industry and
\end{abstract}


Trade Service 2016-2019 seen from the Independence Ratio can be categorized as Independent, because the average ratio of Independence is $96.66 \%$. The effectiveness ratio is classified as less effective because it has not met the target each year. Meanwhile, the efficiency ratio cannot be calculated using the efficient ratio formula because the costs incurred for Regional Original Revenue at the Blitar Regency Industry and Trade Service are not the costs incurred from the original Regional Revenue but from the APBD. Therefore, the Efficient Ratio in the Office of Industry and Trade in Blitar Regency cannot be defined for its financial performance.

\section{Keywords: Financial Performance, Independence Ratio, Effectiveness Ratio, Efficiency Ratio}

\section{PENDAHULUAN}

Analisis kinerja pengelolaan keuangan dan kemandirian daerah adalah suatu proses penilaian mengenai tingkat kemajuan pencapaian pelaksanaan pekerjaan/kegiatan dalam bidang keuangan untuk kurun waktu tertentu. Pengukuran kinerja pemerintah daerah banyak memiliki tujuan yang berfungsi untuk meningkatkan kinerja dan meningkatkan akuntabilitas pemerintah daerah. Pemerintah daerah didorong untuk mampu menciptakan ukuran kinerja yang baik, dan memiliki inovasi untuk lebih memperbaiki ukuran kinerja. Ukuran kinerja dapat mempengaruhi ketergantungan antar unit kerja yang ada dalam satu kerja (Mardiasmo, 2002:299).

Tujuan pengukuran Kinerja Pengelolaan Keuangan Pemerintah Daerah menurut Mardiasmo (2002:121) adalah untuk memenuhi tiga maksud, yaitu 1) untuk memperbaiki kinerja pemerintah, ukuran kinerja dimaksudkan untuk membantu pemerintah berfokus pada tujuan dan sasaran program unit kerja, sehingga pada akhirnya akan meningkatkan efektivitas dalam memberi pelayanan publik, 2) untuk mengalokasikan sumber daya dan pembuatan keputusan, 3) untuk mewujudkan pertanggungjawaban publik dan memperbaiki komunikasi kelembagaan.

Jumingan (2006:242) menjelaskan kinerja keuangan dapat dinilai dengan beberapa alat analisis. Berdasarkan tekniknya, analisis keuangan dapat dibedakan menjadi 8 macam, yaitu analisis perbandingan laporan keuangan, analisis tren (tendensi posisianalisis persentase per komponen (common size), analisis sumber dan penggunaan modal kerja, analisis sumber dan penggunaan kas, analisis rasio keuangan, analisis perubahan laba kotor, dan analisis break even. Ini berarti kinerja keuangan dapat dinilai dari analisis rasio keuangan.

Ukuran tingkat kemandirian lembaga pemerintahan daerah dengan membandingkan besarnya pendapatan asli daerah dengan total pendapatan daerah, dengan asumsi kemandirian sangat rendah, rendah, sedang, dan tinggi. Kemudian efektivitas pendapatan asli daerah menunjukan seberapa efektif daerah dalam merealisasikan pendapatan asli daerah yang telah dianggarkan sebelumnya dengan asumsi realisasi pendapatan asli daerah efektif atau tidak. Halim (2002) juga menyebutkan bahwa efisiensi adalah rasio yang menggambarkan perbandingan antara besarnya biaya yang dikeluarkan untuk memperoleh pendapatan dengan 
realisasi pendapatan yang diterima. Kinerja pemerintah daerah dalam melakukan pemungutan pendapatan dikategorikan efisien, apabila rasio yang dicapai kurang dari 1 (satu) atau di bawah 100\% karena semakin kecil rasio efisien maka kinerja pemerintah semakin baik.

\section{TINJAUAN PUSTAKA}

\section{Pengertian Kinerja Keuangan}

Sucipto (2003) menjelaskan kinerja keuangan adalah penentuan ukuranukuran tertentu yang dapat mengukur keberhasilan suatu organisasi atau perusahaan dalam menghasilkan laba. Sedangkan menurut IAI (2007) Kinerja Keuangan adalah kemampuan perusahaan dalam mengelola dan mengendalikan sumberdaya yang dimilikinya.

\section{Indikator Kinerja Keuangan}

Jumingan (2006:242) menjelaskan kinerja keuangan dapat dinilai dari 8 macam indikator antara lain Analisis Perbandingan Laporan Keuangan, Analisis Tren, Analisis Persentase Per Komponen, Analisis Sumber dan Pengguanaan Modal Kerja, Analisis Sumber dan Penggunaan Kas, Analisis Rasio Keuangan, Analisis Perubahan Laba Kotor dan Analisis Break Even.

\section{Tujuan Pengukuran Kinerja Keuangan}

Tujuan pengukuran kinerja keuangan menurut Mardiasmo (2002:121) adalah untuk memperbaiki kinerja pemerintah, untuk mengalokasikan sumber daya dan pembuatan keputusan dan untuk mewujudkan pertanggungjawaban publik dan memperbaiki komunikasi kelembagaan.

\section{Analisis Rasio Keuangan}

Jumingan (2006:242) menjelaskan analisis rasio keuangan merupakan analisis dengan membandingkan satu pos laporan dengan pos laporan keuangan yang lain. Rasio menggambarkan suatu hubungan dan perbandingan antara jumlah tertentu salam satu pos laporan keuangan dengan jumlah yang lain pada pos laporan keuangan yang lain. Dengan menggunakan metode analisis seperti rasio ini dapat menjelaskan atau memberikan gambaran tentang baik burunya keadaan atau posisi keuangan atau kinerja suatu lembagan pemerintahan. Dengan rasio keuangan ini juga dapat membantu lembaga pemerintahan dalam mengidentifikasi kekuatan dan kelemahan suatu lembaga pemerintahan dalam kinerja keuangannya.

\section{Pengertian Laporan Keuangan}

Kasmir (2012:7) menjelaskan laporan keuangan adalah laporan yang menunjukkan kondisi keuangan lembaga pada saat ini atau dalam suatu periode tertentu. Sedangkan Subramanyam (2012) menejelaskan laporan keuangan adalah produk proses pelaporan keuangan yang diatur oleh standar dan aturan akuntansi, insentif manajer, serta mekanisme pelaksanaan dan pengawasan perusahaan.

\section{Tujuan Laporan Keuangan}

Standar Akuntansi Keuangan (2015) menyatakan bahwa tujuan laporan keuangan adalah menyediakan informasi yang menyangkut posisi keuangan, kinerja serta perubahan posisi keuangan suatu entitas yang bermanfaat bagi sejumlah besar pengguna dalam pengambilan keputusan ekonomik. 


\section{Jenis-jenis Laporan Keuangan}

Hanafi (2014:12) menjelaskan secara umum ada tiga laporan keuangan yang dihasilkan oleh suatu organisasi yaitu neraca, laporan laba rugi, laporan perubahan modal dan laporan aliran kas.

\section{Pengertian Analisis Laporan Keuangan}

Subramanyam (2012:3) menejelaskan bahwa analisis laporan keuangan merupakan analisis dari alat dan teknik analitis untuk laporan keuangan bertujuan umum dan data-data yang berkaitan untuk menghasilkan estimasi dan kesimpulan yang bermanfaat dalam analisis bisnis.

\section{METODE PENELITIAN}

\section{Waktu dan Lokasi Penelitian}

Penelitian ini berlangsung pada bulan Januari s.d Mei tahun 2020. Dilaksanakan di Dinas Perindustrian dan Perdagangan Kabupaten Blitar khususnya pada bidang program dan bagian bendahara dinas.

\section{Jenis Peneliatian}

Penelitian ini menggunakan metode deskriptif kuantitatif. Sugiyono (2013:11) mendefinisikan metode penelitian kuantitatif diartikan sebagai metode penelitian yang berlandasakan pada filsafat positivisme, digunakan untuk meneliti pada polulasi atau sampel tertentu, teknik pengambilan sampel pada umumnya dilakukan secara random, pengumpulan data menggunakan instrumen penelitian, analisis data bersifat kuantitatif/statistik dengan tujuan menguji hipotesis yang ditetapkan. Moh Nazir (2005:54) menjelaskan bahwa metode penelitian deskriptif adalah suatu metode dalam meneliti status kelompok manusia, suatu objek, suatu set kondisi, suatu sistem pemikiran ataupun suatu kelas peristiwa pada masa sekarang.

\section{Variabel Penelitian}

Penelitian ini bertujuan untuk menganalisis perkembangan kinerja keuangan Dinas Perindustrian dan Perdagangan Kabupaten Blitar tahun anggaran 2016-2019. Untuk menganalisis kinerja keuangan pemerintah pemerintah daerah tersebut, menggunakan analisis rasio keuangan yang berupa rasio tingkat kemandirian, efektivitas, dan efisiensi.

\section{Teknik Pengumpulan Data}

Studi dokumentasi adalah pengumpulan data dengan mengkaji dokumen dan bahan-bahan tertulis atau cetak yang berkaitan dengan masalah penelitian. Dokumen-dokumen dan data-data tersebut merupakan alat yang membantu di dalam penelitian, hal tersebut meliputi laporan keuangan Dinas Perindustrian dan Perdagangan Kabupaten Blitar dan literatur yang membahas tentang kinerja keuangan.

\section{Teknik Analisis Data}

Sesuai dengan penelitian yang dilakukan maka teknik analisa data yang digunakan adalah deskriptif kuantitatif yaitu melakukan perhitungan-perhitungan terhadap data keuangan yang diperoleh untuk memecahkan masalah yang ada sesuai dengan tujuan penelitian. 


\section{HASIL PENELITIAN DAN PEMBAHASAN}

\section{Hasil Penelitian}

Rasio Kemandirian

Hasil dari perhitungan dari Rasio Kemandirian dapat dilihat ditabel dibawah ini:

Tabel 1. Tingkat Kemandirian Dinas Perindustrian dan Perdagangan Kabupaten Blitar Tahun Anggaran 2016-2019

\begin{tabular}{|c|c|c|c|c|}
\hline $\begin{array}{c}\text { Tahun } \\
\text { Anggaran }\end{array}$ & $\begin{array}{c}\text { Pendapatan Asli } \\
\text { Daerah }\end{array}$ & $\begin{array}{c}\text { Total } \\
\text { Penerimaan }\end{array}$ & $\begin{array}{c}\text { Rasio } \\
\text { Kemandirian }\end{array}$ & Keterangan \\
\hline (a) & (b) & (c) & $(\mathrm{d})=(\mathrm{b}) /(\mathrm{c})$ & $(\mathrm{e})$ \\
\hline 2016 & 3.261 .269 .600 & 3.273 .769 .600 & $99,62 \%$ & Mandiri \\
\hline 2017 & 3.687 .014 .600 & 3.712 .514 .600 & $99,31 \%$ & Mandiri \\
\hline 2018 & 4.187 .745 .500 & 4.200 .245 .500 & $99,70 \%$ & Mandiri \\
\hline 2019 & 4.303 .101 .900 & 4.889 .918 .063 & $88,00 \%$ & Mandiri \\
\hline
\end{tabular}

Sumber Data: DISPERINDAG Kabupaten Blitar (diolah)

Berdasarkan hasil perhitungan tabel 1. diatas kemampuan keuangan Dinas Perindustrian dan Perdagangan Kabupaten Blitar tergolong sudah benar-benar mampu dan mandiri untuk melaksanakan urusan otonomi daerah. Nilai terendah terjadi pada tahun 2019 dimana nilainya sebesar 88,00\% dan nilai tertinggi terdapat pada tahun 2018 yaitu sebesar $99,70 \%$. Pada tahun yang lainnya yaitu tahun 2016 dan 2017 masing-masih nilai yang dicapai sebesar 99,62\% dan $99,31 \%$. Hal ini menunjukan bahwa tingkat ketergantungan terhadap bantuan dari pemerintah pusat bisa dikatakan sudah sangat kecil.

Rasio Efektivitas

Hasil perhitungan Rasio Efektivitas dapat dilihat pada tabel di bawah ini:

Tabel 2. Penghitungan Rasio Efektivitas Dinas Perindustrian dan Perdagangan Kabupaten Blitar Tahun Anggaran 2016-2019

\begin{tabular}{|c|c|c|c|c|}
\hline $\begin{array}{c}\text { Tahun } \\
\text { Anggaran }\end{array}$ & $\begin{array}{c}\text { Realisasi } \\
\text { Penerimaan }\end{array}$ & $\begin{array}{c}\text { Target } \\
\text { Penerimaan }\end{array}$ & $\begin{array}{c}\text { Rasio } \\
\text { Efektivitas }\end{array}$ & Keterangan \\
\hline (a) & $(\mathrm{b})$ & $(\mathrm{c})$ & $(\mathrm{d})=(\mathrm{b}) /(\mathrm{c})$ & $(\mathrm{e})$ \\
\hline 2016 & 3.273 .769 .600 & 3.851 .099 .600 & $85,01 \%$ & $\begin{array}{c}\text { Tidak } \\
\text { Efektif }\end{array}$ \\
\hline 2017 & 3.712 .514 .600 & 4.083 .156 .800 & $90,92 \%$ & $\begin{array}{c}\text { Tidak } \\
\text { Efektif }\end{array}$ \\
\hline 2018 & 4.200 .245 .500 & 4.479 .662 .192 & $93,76 \%$ & $\begin{array}{c}\text { Tidak } \\
\text { Efektif }\end{array}$ \\
\hline 2019 & 4.889 .918 .063 & 4.508 .634 .692 & $108,46 \%$ & Efektif \\
\hline
\end{tabular}

Sumber Data: DISPERINDAG Kabupaten Blitar (diolah)

Berdasarkan perhitungan di tabel 2. di atas dapat diketahui bahwa efektivitas Keuangan Dinas Perindustrian dan Perdagangan Kabupaten Blitar pada tahun 2016-2018 tidak efektif, karena nilai yang diperoleh masih di bawah $100 \%$ yaitu $85,01 \%, 90,92 \%$ dan 93,76\%. Untuk tahun 2019 sudah efektif karena nilai yang diperoleh sudah lebih dari $100 \%$ yaitu $108,46 \%$.

Rasio Efisien 
Hasil dari perhitungan Rasio Efisien dapat dilihat pada tabel di bawah ini: Tabel 3. Perhitungan Rasio Efisien Dinas Perindustrian dan Perdagangan Kabupaten Blitar Tahun Anggaran 2016-2019

\begin{tabular}{|c|c|c|c|c|}
\hline $\begin{array}{c}\text { Tahun } \\
\text { Anggaran } \\
\end{array}$ & $\begin{array}{c}\text { Biaya } \\
\text { Dikeluarkan }\end{array}$ & $\begin{array}{c}\text { Realisasi } \\
\text { Penerimaan }\end{array}$ & $\begin{array}{l}\text { Rasio } \\
\text { Efisien }\end{array}$ & Keterangan \\
\hline (a) & (b) & (c) & $(\mathrm{d})=(\mathrm{b}) /(\mathrm{c})$ & (e) \\
\hline 2016 & - & 3.273 .789 .600 & - & - \\
\hline 2017 & - & 3.712 .514 .600 & - & - \\
\hline 2018 & - & 4.200 .245 .500 & - & - \\
\hline 2019 & - & 4.889 .913 .063 & - & - \\
\hline
\end{tabular}

Sumber Data: DISPERINDAG Kabupaten Blitar (diolah)

Berdasarkan perhitungan pada Tabel 3. di atas dapat diketahui bahwa Dinas Perindustrian dan Perdagangan Kabupaten Blitar dalam penghitungan rasio efisien tidak bisa dilakukan karena biaya yang dikeluarkan untuk biaya Pendapatan Asli Daerah merupakann biaya dari anggaran APBD bukan dari hasil retribusi yang diperoleh ataupun dari Pendapatan Asli Daerah itu sendiri.

\section{Pembahasan}

Rasio Kemandirian

Rasio kemandirian Dinas Perindustrian dan Perdagangan Kabupaten Blitar tahun 2016.

$$
\text { Rasio Kemandirian }=\frac{3.261 .269 .600}{3.273 .769 .600} \times 100 \%=\mathbf{9 9 , 6 2} \%
$$

Tingkat kemandirian Dinas Perindustrian dan Perdagangan Kabupaten Blitar pada tahun 2016 adalah 99,62\%. Nilai rasio kemandirian tersebut menunjukkan bahwa tingkat kemandirian dinas dikatakan mandiri, tidak bergantung dengan pendapatan dari luar yang dapat berupa pendapatan lain-lain. tahun 2017.

Rasio kemandirian Dinas Perindustrian dan Perdagangan Kabupaten Blitar

$$
\text { Rasio Kemandirian }=\frac{3.687 .014 .600}{3.712 .514 .600} \times 100 \%=\mathbf{9 9 , 3 1} \%
$$

Tingkat kemandirian Dinas Perindustrian dan Perdagangan Kabupaten Blitar tahun 2017 mengalami penurunan yaitu sebesar 0,31\%. Pada tahun sebelumnya kemandirian Dinas Perindustrian dan Perdagangan Kabupaten Blitar sebesar 99,62\% sedangkan ditahun 2017 mengalami penuruan, tetapi tidak dianggap sebagai nilai rendah karena dari jumlah pendapatan asli daerah terus memberikan peningkatan, maka dari itu tingkat kemandirian Dinas Perindustrian dan Perdagangan Kabupaten Blitar masih dikatakan baik. tahun 2018 .

Rasio kemandirian Dinas Perindustrian dan Perdagangan Kabupaten Blitar

$$
\text { Rasio Kemandirian }=\frac{4 \cdot 187.745 .500}{4.200 .245 .500} \times 100 \%=\mathbf{9 9 , 6 2} \%
$$

Tingkat kemandirian Dinas Perindustrian dan Perdagangan Kabupaten Blitar tahun 2018 mengalami peningkatan. Pada tahun 2017, kemandirian Dinas Perindustrian dan Perdagangan Kabupaten Blitar sebesar 99,31\%, sedangkan saat tahun 2018 naik menjadi 99,70\%. Menunjukan bahwa tingkat kemandirian keuangan Dinas Perindustrian dan Perdagangan Kabupaten Blitar baik. 
Rasio kemandirian Dinas Perindustrian dan Perdagangan Kabupaten Blitar tahun 2019.

$$
\text { Rasio Kemandirian }=\frac{4.303 .101 .900}{4.889 .918 .063} \times 100 \%=\mathbf{8 8 , 0 0} \%
$$

Tingkat kemandirian Dinas Perindustrian dan Perdagangan Kabupaten Blitar tahun 2019 mengalami penurunan yang signifikan yaitu sebesar 11,70\%. Pada tahun sebelumnya kemandirian Dinas Perindustrian dan Perdagangan Kabupaten Blitar sebesar 99,70\% sedangkan ditahun 2017 mengalami penuruan, dikarenakan pada pendapatan lain-lain mengalami lonjakan yang jauh lebih banyak dari tahun-tahun sebelumnya. Tetapi tidak dianggap sebagai nilai rendah karena dari jumlah pendapatan asli daerah terus memberikan peningkatan, maka dari itu tingkat kemandirian Dinas Perindustrian dan Perdagangan Kabupaten Blitar masih dikatakan baik.

Rasio Efektivitas

Pada tahun anggaran 2016 jumlah realisasi sebesar Rp. 3.273.769.600, sedangakan target penerimaan pendapatan asli daerah sebesar 3.851.099.600, dari perbandingan di atas dapat dilihat bahwa jumlah realisasi lebih kecil dari pada target penerimaan sehingga dapat disimpulkan pada tahun anggaran 2016 penerimaan tidak mencapai target.

Pada tahun anggaran 2017 mengalami peningkatan dari tahun sebelumnya. Namun dilihat dari perbandingan tingkat penerimaan realisasi dan target, pada tahun 2017 penerimaan tidak mencapai target karena jumlah realisasi Rp. 3.712.514.600 sedangkan jumlah target sebesar Rp. 4.083.156.800 sehingga jumlah target lebih besar dari pada jumlah realisasi.

Pada tahun anggaran 2018 tingkat pendapatan realisasi dan target penerimaan mengalami peningkatan yaitu sebesar Rp. 4.200.245.500 dan Rp. 4.479.662.192 sehingga dapat dilihat bahwa pendapatan meningkat dari tahun sebelumnya. Namun dari perbandingan tersebut, pada tahun 2018 dapat disimpulkan tidak mencapai target karena jumlah target lebih besar dibanding jumlah realisasi.

Pada tahun 2019 jumlah realisasi dan jumlah target penerimaan pendapatan asli daerah mengalami peningkatan yang signifikan dibanding dengan tahun-tahun sebelumnya yaitu sebesar Rp. 4.889.918.063 dan Rp. 4.508.634.692, sedangkan perbandingannya juga mengalami peningkatan dari tahun sebelumnya dan dapat disimpulkan bahwa di tahun 2019 telah mencapai target yang ditetapkan.

Rasio Efisien

Pada perhitungan Rasio Efisien yang coba diaplikasikan untuk menghitung tingkat efisien Dinas Perindustrian dan Perdagangan Kabupaten Blitar tidak bisa diterapkan. Karena menurut rumus Rasio Efisien yaitu biaya yang dikeluarkan untuk Pendapatan Asli Daerah pada Dinas Perindustrian dan Perdagangan Kabupaten Blitar biaya yang dikeluarkan bukan dari hasil Pendapatan Asli Daerah melainkan dari APBD. Maka dari itu Rasio Efisien di Dinas Perindustrian dan Perdagangan Kabupaten Blitar tidak bisa didefinisikan kinerja keuangannya. 


\section{KESIMPULAN DAN SARAN}

\section{Kesimpulan}

Tingkat kemandirian Dinas Perindustrian dan Perdagangan Kabupaten Blitar yang diukur melalui pendapatan asli daerah berupa retribusi pelayanan pasar mencapai rata-rata 99,07\% untuk tahun anggaran 2016-2019 dengan peningkatan tiap tahun anggaran sebesar 3,44\%. Rata-rata pendapatan asli daerah yang diperoleh melalui hasil retribusi pelayanan pasar terhadap total penerimaan telah mendekati sempurna yaitu 96,66\%, sehingga tingkat rasio kemandirian Dinas Perindustrian dan Perdagangan Kabupaten Blitar dinilai tinggi dan dapat dikatakan mampu untuk melaksanakan otonomi keuangan daerah. Tingkat efektivitas pendapatan daerah khususnya Dinas Perindustrian dan Pedagangan Kabupaten Blitar selama tahun 2016-2019 rata-rata sebesar 94,54\% dengan peningkatan setiap tahun sebesar 7,82\% dengan demikian pemungut pendapatan asli daerah dinilai kurang efektif, karena kontribusi yang diberikan terhadapat target yang diinginkan kurang dari $100 \%$. Tingkat efisien tidak bisa dihitung dengan rumus rasio efisien karena biaya yang dikeluarkan untuk Pendapatan Asli Daerah pada Dinas Perindustrian dan Perdagangan Kabupaten Blitar biaya yang dikeluarkan bukan dari hasil Pendapatan Asli Daerah melainkan dari APBD. Maka dari itu Rasio Efisien di Dinas Perindustrian dan Perdagangan Kabupaten Blitar tidak bisa didefinisikan kinerja keuangannya.

\section{Saran}

Pemerintah daerah khususnya Dinas Perindustrian dan Pedagangan Kabupaten Blitar sebaiknya lebih meningkatkan kinerja pemungutan pendapatan asli daerah supaya dapat memenuhi target dan meningkatankan potensi yang tersedia untuk bisa dikatakan layak untuk membantu otonomi pemerintah daerah.

\section{DAFTAR PUSTAKA}

Abdul Halim. 2002. Akuntansi Sektor Publik. Jakarta: Salemba Empat.

Ahmad Yani, 2008, Hubungan Keuangan antara Pemerintah Pusat dan Pemerintah Daerah di Indonesia, Jakarta, Rajawali Pers.

B. Uno, Hamzah. 2008. Teori Motivasi dan Pengukurannya, Jakarta: Bumi Aksara.

Bastian, Indra. 2006. Akuntansi Sektor Publik: Suatu Pengantar. Jakarta: Erlangga.

Baswir, Revrisond. (2000). Akuntansi Pemerintahan Indonesia. Yogyakarta: BPFE.

Darise, N. 2008. Akuntansi Keuangan Daerah, Jakarta: PT Indeks.

Darsono. 2005. Pedoman Praktis Memahami Laporan Keuangan. Salemba Empat. Jakarta. 
Dwi Prastowo, Rifka Juliaty. 2002. Analisis Laporan Keuangan Konsep dan Aplikasi. Yogyakarta : Unit Penerbit \& Percetakan AMP YKPN.

Fahmi, Irham. 2011. Analisis Laporan Akuntansi. Bandung: ALFABETA.

Hanafi, Mamduh M. dan Abdul Halim, 2014, Analisis Laporan Keuangan., Edisi tujuh., UPP AMP YKPN, Yogyakarta.

Hanif Nurcholis, 2007, Teori dan Praktik Pemerintahan dan Otonomi Daerah, Jakarta: Grasindo.

Harahap, Sofyan Syafri. 2009. Analisis Kritis Atas Laporan Keuangan. Jakarta: PT Raja Grafindo Persada

Ikatan Akuntan Indonesia. 2007. Standar Akuntansi Keuangan. Jakarta: Salemba

Ikatan Akuntan Indonesia. 2015. Pernyataan Standar Akuntansi Keuangan. Jakarta : Ikatan Akuntan Indonesia.

John J, Wild, (2005). Analisa Laporan Keuangan, Buku Dua, diterjemahkan Oleh Yanivi S. Yogyakarta: Salemba Empat.

Jumingan. 2006. Analisis Laporan Keuangan. Jakarta: PT. Bumi Aksara.

Kasmir. (2012), Analisis Laporan Keuangan. Jakarta: PT. Raja Grafindo Persada.

Mardiasmo. (2002). Akuntansi Sektor Publik. Yogyakarta: Andi.

Mardiasmo. 2011. Perpajakan Edisi Revisi. Yogyakarta: Andi.

Munawir. 2012. Analisis Laporan Keuangan. Liberty. Yogyakarta

Nazir, Moh. 2005. Metode Penelitian. Jakarta: Ghalia Indonesia.

Nordiawan, Deddi. (2008). Akuntansi Pemerintahan. Jakarta: Salemba Empat.

Ross, Westerfield \& Jordan. 2004.Corporate Finance Fundamentals.The McGraw-hill companies. New York.

Subramanyam dan John J. Wild. 2012. Analisis Laporan Keuangan. Jakarta: Salemba Empat.

Sucipto. 2003. "Penilaian Kinerja Keuangan.” Jurnal Akuntansi. Universitas Sumatra Utara. Medan.

Sugiyono. 2010. Metode Penelitian Pendidikan Pendekatan Kuantitatif, kualitatif, dan $R \& D$. Bandung: Alfabeta

Sugiyono. 2012.Metode Penelitian Bisnis. Bandung : Alfabeta.

Sugiyono. 2013. Metode Penelitian Pendidikan Pendekatan Kuantitatif, Kualitatif, dan $R \& D$. Bandung: Alfabeta. 
Jurnal Cendekia Akuntansi Vol. 2 No.1

Syamsuddin, Lukman. 2013. Manajemen Keuangan Perusahaan. PT. Raja Grafindo Persada: Jakarta.

Tanjung, A.H. (2009). Penatausahaan dan Akuntansi Keuangan Daerah untuk SKPD. Jakarta. Salemba Empat.

Tanjung, Abdul Hafiz. (2008). Akuntansi Pemerintahan Daerah. Bandung: Alfabeta.

Wulandari, Iryanie. 2018. Pajak Daerah dalam Pendapatan Asli Daerah. Yogyakarta: Penerbit Dee Publish.

Wulandari, P.A., \& Iryanie, E. (2018). Pajak Daerah dalam Pendapatan Asli Daerah. Yogyakarta. CV Budi Utama. 